"Seeing to be seen":

\title{
The manager's political economy of visibility in new ways of working
}

\author{
Aurélie Leclercq-Vandelannoitte, Ph.D \\ CNRS, LEM (URM 9221), IESEG School of Management, 59000 Lille, France. \\ Researcher, CNRS (National Center for Scientific Research), France \\ a.leclercq@ieseg.fr \\ 3 rue de la digue, 59000 Lille, France
}

\begin{abstract}
Recent changes in the world of work have modified the conditions of the exercise of management in ways that challenge managers' traditional authority and identity, both symbolically and physically. In this context, we analyse the "visibilizing process" of managers, through which they attempt to make themselves more visible, in ways that reaffirm their authority and restore their identity as managers. To that end, we develop a Foucauldian framework on power and visibility, which sheds light on the "political economy of visibility" of the manager. We apply this framework to a case study that encouraged a re-spatialization of remote work in coworking spaces. The findings show how the manager in our case study staged his own visibility, by enhancing managerial control, to manage his invisibility and shape his intertwined identities. Through the visibilizing process, the manager legitimated his role, materialized his function, and restored his authority.
\end{abstract}

Keywords: Manager's identity; Authority; Control; New ways of working; Coworking space; Remote work; Michel Foucault; Visibility vs Invisibility; Exploratory case study; Political economy of visibility 


\section{Introduction}

In recent years, managers' roles and identities have been subject to powerful pressures. Recent changes have modified the conditions of the exercise of management in ways that alter perceived managerial authority (Foster, Hassard, Morris, \& Cox, 2019). In particular, the shift from bureaucratic hierarchies to post-bureaucratic organizations (Heckscher \& Donnellon, 1994; Hodgson, 2004) has challenged the power and underlying legitimacy of the manager, as supervisory responsibilities and control increasingly move outward to empowered employees and distant and self-managed teams. Some commentators even predict the "end of management" (Murray, 2010) or, at least, the demise of the traditional manager (Hales, 2005). Rather than classic supervisors, managers have increasingly begun to function as detached and liberating leaders (Carney \& Getz, 2009; Clegg, Harris, \& Hopfl, 2011), coaches, facilitators, or coordinators (Hales, 2005). In this context, new ways of working (NWW) (e.g., flexible, remote work arrangements, or telework; Aroles et al., 2019) have modified the conditions of the exercise of management. In particular, they have disrupted taken-for-granted supervisory arrangements, based on direct supervision and the visibility of employees (Sewell \& Taskin, 2015). Characterized by fragmentation (Kallinikos, 2003), liquefaction (Bauman, 2000), distantiation (Taskin, 2010), and "dis-location" of managers (Halford, 2005), subordinates, and peers, NWW imply that employees are less visible and escape managers' direct supervision (Allard-Poesi \& Laroche, 2018). The capacity to decouple work activity from the physical constraints imposed by offices indeed alters managers' visibility over employees and, as such, the disciplinary force they can exert on their conduct (Sewell, 2012).

With these changes, it is not just employees who have become less visible. Changes in the world of work and in the conditions of the exercise of management have also eroded perceptions of managers' authority, both symbolically and physically, in ways that make their power less visible, their presence less palpable, and their attributes (e.g., their control potential) less evident. Traditional managerial authority has long been embedded in the physical proximity to subordinates (Ropo, Salovaara, Sauer, \& de Paoli, 2015) and the exercise of specific control and supervisory roles in embodied form (Halford, 2005). Managers and leaders are made manifest through their material presence, their physical, corporeal, and visible aspects (Ford, Harding, Gilmore, \& Richardson, 2017).

In this context, research has shown that managers tend to compensate for the distance, absence, and invisibility of their remote subordinates by applying new formalized or bureaucratic systems and disciplinary uses of information technology (IT) (Sewell \& Taskin, 2015), 
constituting modern forms of "panoptic" surveillance (Foucault, 1977). NWW are thus often associated, in contrast with discourses celebrating empowerment and organizational flattening, with the resurgence of bureaucratic and disciplinary protocols geared toward reintroducing some form of surveying gaze at a distance over employee behaviour (Fleming, 2009; Sewell \& Taskin, 2015). By doing so, managers attempt to gain more visibility over their employees, but, we contend that, at the same time, they may also attempt to make themselves more visible, in ways that reaffirm their authority and restore their identity as managers.

However, this "visibilizing process" of the manager is absent in management and organization literature. While a great deal of research has explored how employees' behaviours are subjected to new forms of control and surveying gaze at a distance, through modern dispositives that make their work more visible and support the potential for panoptic-based continuous surveillance (Dandeker, 1990; Zuboff, 1988), the visibilizing process of the manager has been far less investigated. The objective of this research is thus to analyse recent evolutions of managers' authority, as part of their identity construction process, in the context of NWW that alter classic supervisory conditions and may erode their authority. We aim to understand how managers' roles and identities are affected by organizational changes that challenge their authority and how managers try to restore their authority by staging their own visibility. Thus, we ask: How do managers shape their roles and identities by engaging in practices that enhance their own visibility?

To address our research question, we base our work in the context of organizational politics and draw on Michel Foucault's (1977, 1980) original conceptualization of power dynamics embedded in a "political economy of visibility". We believe that Foucault's philosophy, in particular his development on power, control, and visibility, beyond the mere classic panopticon metaphor, offers insightful conceptual tools that allow us to explore and critically apply the construct of the political economy of visibility to the manager.

We apply the Foucauldian framework to a concrete exploratory, ethnographic qualitative case study of a Belgian knowledge-based company specializing in digital transformation, in which the manager introduced a policy of voluntary part-time work in coworking spaces (CS) for remote employees. Aiming to make sense of the evolutions in managers' authority and roles in the context of re-spatialization of remote employees' work, we highlight the embeddedness of the manager in a political economy of visibility, involving active meaning-making processes through which this manager justifies his existence. 
We first provide an overview of the relevant literature on the manager's role and identity and analyse the challenges to and evolutions of managerial authority in post-bureaucratic NWW. Then, we outline the relevance of a Foucauldian framework to build the construct of a political economy of visibility that we apply to the manager's role. These concepts provide a backdrop for exploring the evolution of managerial authority, roles, and identities in the context of NWW in a real case. Finally, we discuss our findings and offer some conclusions. The novelty of our contribution lies in the reversion of classic logics of visibility found in traditional management and organizational literature (in which visibility generally applies to the work of employees), as our research reveals how this visibilizing process also applies to the manager. We contribute to research on the manager's evolving role and identity-building process by showing, through a Foucauldian analysis of the manager's political economy notion of visibility, how the manager in our case staged his own visibility to manage his invisibility. Through this visibilizing process, he shaped his identity and justified his existence. Overall, we show that in turbulent times and an evolving organizational context in which managers' authority is subject to strong pressures, managerial identity can be conceived of as a social process and a co-constituted continual accomplishment; we also highlight the spatial and material dimensions of the management of meaning in the "legitimating" process of managers.

\section{Literature review}

\subsection{Managers' authority and control as constitutive of managerial identity}

Many conceptualizations of identity, and of managerial identity in particular, exist in organization studies, but all share the idea that identities are what make people's inner and social worlds intelligible and manageable (Swann \& Bosson, 2010). Managerial identity thus specifies how managers define themselves and their work, describes what being a manager means, justifies what being a manager feels like, and prescribes what a manager can do and with whom.

However, the identity and activity of managers remain complex and difficult to grasp, such that what managers actually do in organizations can best be described in terms of specific "roles" or organized sets of behaviours identified for a position (from interpersonal to informational and decisional roles) (Mintzberg, 1973). Organizational research particularly underscores that managers are vested with "formal authority" over organizational units, from which comes status, which leads to various interpersonal relations. Among such roles and relations, 
managerial control is one of the most visible functions of managers (Mintzberg, 1983). Control, which is often equated with management, is a direct implication of their formal authority, one of the most visible attributes of their power, and a "dominant part of their job" (Alvesson \& Karreman, 2004, p. 424). As such, control is constitutive of managerial identity (Sveningsson \& Alvesson, 2003, Wiesenfeld, Ragurham, \& Garud, 1999). Control is indeed crucial to ensure that organizational actors behave in ways that lead to the attainment of organizational objectives (Flamholtz, 1996). Managerial authority is both essential to exert such control and an ostensible manifestation of the manager's control potential.

Managerial or "hierarchical authority" has long been considered embedded in the structure of organizational roles, expertise, and positions (Mintzberg, 1983). However, recent research has shown that its enactment and justification in organizational contexts also rely on a set of discursive practices. Managerial authority often gives rise to power struggles, negotiations, and various political actions and relationships (Allard-Poesi \& Laroche, 2018). Managerial authority indeed depends on others' perceptions and negotiations to exist as such and persist over time, such that managerial authority cannot be performed or enacted without the implicit acquiescence of others embedded in a specific political context. Recent socio-material accounts of authority also indicate that the performance of authority involves not just people but also a broader range of actants, including artefacts (Taylor \& Van Every, 2014) and abstract entities (Bourgoin, Bencherki, \& Faraj, 2019), that constantly evolve depending on relationships and power dynamics.

\subsection{Challenges to managerial authority and identity}

In recent years, the authority, role, and constitutive identity of managers have undergone considerable changes (Bourgoin et al., 2019; Hassard et al., 2009) as a result of a deep alteration of the world of work, which tends to make the traditional figure of the manager less visible, both symbolically and physically. A shift from bureaucratic hierarchies to post-bureaucratic organizations and networks (Drucker, 1988; Heckscher \& Donnellon, 1994; Kanter, 1989; Mintzberg, 1998) has led to the emergence of more responsive organizational forms, based on flat, neo-bureaucratic lines accompanied by delayering, decentralization, and the empowerment of employees (Carney \& Getz, 2009; Foster et al., 2009; Hales, 2005; Hamel, 2011; Seibert, Silver, \& Randolph, 2004). This shift from bureaucratic hierarchies to post-bureaucratic organizations (Heckscher \& Donnellon, 1994) has led to radical changes in managerial work, particularly in the manager's control function (Hales, 2005) and authority. This move has triggered an evolution of the manager's role from direct forms of control laid down by hierarchy 
(supervision and behavioural control) to more indirect, emergent, decentralized, and negotiated forms (derived from the management by objectives, clan control, and self-control; Hodgson, 2004; Ouchi, 1979).

These evolutions are celebrated, symbolically, in the frame of a broader societal discourse emphasizing the increasing "uselessness" of middle management, epitomized by the rapid development of self-managing and "adhocratic organizations" (Peters, 1992), organizational democracy (Lee \& Edmonson, 2017), "holacracy" (Robertson, 2015), and "liberated companies" (Carney \& Getz, 2009), in which the traditional figure of the manager has less and less place. Such evolutions indeed make old management and leadership models obsolete (Hamel, 2011; Koch \& Godden, 1997; Leavitt, 2003). Rather than working as classic, day-today supervisors, managers are increasingly called to function as "detached" teams or "project leaders" (Clegg et al., 2011), coaches, facilitators, or coordinators, charged with the fuzzy, unregulated task of facilitating the activity of a network of actors both inside and outside the organization (Hales, 2005). Such evolutions thus tend to erode managerial authority and even to erase the classic figure of the manager (Hales, 2005; Murray, 2010).

In addition, so-called NWW have recently altered the physical structures of the "visibility", "presence", and "absence" of both managers and employees (Felstead, Jewson, \& Walters, 2003) and affected the way work has traditionally been organized and controlled (Kurland \& Cooper, 2002). NWW (e.g., distributed work; coworking; and mobile, remote, virtual, and teleforms of work) make the traditional office - as a cubicle characterized by a triple unity of space, time, and action - obsolete (Johns \& Gratton, 2013). While the constitution of managers and employees has long been embedded in the manager's ability to locate them spatially (Sewell \& Taskin, 2015; Taylor \& Spicer, 2007) and to supervise them directly, such evolutions imply a spatial, temporal, and psycho-social separation of managers, their subordinates, and peers (Sewell \& Taskin, 2015), which affects relationships, roles, and the manager's perceived authority.

In this context, the manager's legitimacy and authority are put under pressure. In particular, one of the essential, most visible, and dominant functions of managers (Mintzberg, 1983) that is constitutive of their identity (Alvesson \& Karreman, 2004; Wiesenfeld et al., 1999) management control-is questioned. NWW indeed represent a deep "cultural change" for organizations, in that they affect the positions, roles, and identities of organizational actors in ways that erode the authority of managers (Balogun \& Johnson, 2004; Bourgoin et al., 2019). 
However, research and empirical observations on NWW highlight paradoxical tensions in the effective evolution of the manager's role.

\subsection{Paradoxical tensions in the evolution of the manager's role}

Research on post-bureaucratic organizations has raised some tensions regarding the effective evolution of the manager's role and the allegedly eroded managerial authority in the context of NWW. Some investigations clearly show a decline in the traditional role and less visible presence of the manager. They indicate diminishing disciplinary forces, thus loosening the reins of managerial control and granting employees new opportunities to exercise autonomy and selfmanagement (Felstead et al., 2003). In such settings, coordination tends to replace managerial control, which is described in more "socio-ideological" terms (Alvesson \& Karreman, 2004), entailing greater interactivity, social focus, commitment, and responsibility from employees. These evolutions clearly move managers to redefine their roles and identity in terms of coaching, leadership, coordination, trust, responsibilization, participation, and supportiveness (Felstead et al., 2003; Kurland \& Cooper, 2002). However, other research shows that NWW are, paradoxically, often coupled with the recapitulation of the traditional manager's role characterized by the exercise of classic modes of control (Hodgson, 2004). A great deal of research highlights managers' attempts to reinforce their visibility at a distance over employees' work and the endurance of bureaucratic control through neo-normative forms (De Peuter, Cohen, \& Saraco, 2017; Fleming, 2009). Indeed, studies have uncovered novel forms of supervisory relationships intended to increase the manager's visibility over remote employees' behaviours, for example, through new forms of performance monitoring applied to distant engineers (Deffayet, 2000), IT-based pervasive forms of control applied to home-based telecommunications workers (Valsecchi, 2006), or new disciplinary uses of electronic monitoring of telesales workers (Dambrin, 2004). Moreover, managers often try to overcome their remote subordinates' invisibility by applying new disciplinary practices, through the symbolic reconstruction of the norms of visibility, presence, and direct supervision traditionally associated with the classic workplace (Sewell \& Taskin, 2015). Sewell and Taskin (2015, p. 1507), for example, explain how IT uses put new constraints on remote employees, who often attempt to reinstate a sense of trust by signalling their availability, commitment, and continuous online presence "in settings that were previously beyond the reach of managerial control". Thus, despite claims of novelty, managers still seem to resort to hierarchies and bureaucratic principles to gain more visibility over their subordinates' behaviours and perform the central core of performance-oriented supervision (Hales, 2005). In this way, hierarchical, control- 
oriented bureaucracies tend to remain the norm in NWW, albeit in a modified form (Alvesson, 1995; Ezzamel, Lilley, \& Willmott, 1994; Reed, 2005). Thus, so-called flattened, modern, liberating organizations still incorporate practices that allow managers to control employees through previously unexpected forms of remote surveillance (Brocklehurst, 2001; Fleming, 2009; Sewell \& Taskin, 2015), such that control still appears as a major part of managerial identity (Hales, 2005), an essence of the managerial job, and an important means to establish authority. In this way, supervision and traditional control strategies seem to remain central to a manager's role and identity (Wiesenfeld et al., 1999) and an evident, visible, perceived manifestation of his or her authority.

Some research argues that the persistence of bureaucratic forms of control as constitutive of managerial authority reflects an enduring reluctance of managers to allow their roles and identities to evolve. Studies highlight managers' resistance to oversee employees whom they cannot physically observe, a lack of trust in employees to supervise themselves (Handy, 1995; Kurland \& Cooper, 2002; Kurland \& Egan, 1999), and an enduring faith in visibility and direct supervision of remote employees as a guarantor of effort or standards (Alvesson, 1995; Ezzamel et al., 1994; Hales, 2005; Kurland \& Cooper, 2002).

We contend that these tensions also reveal managers' attempts to restore their legitimacy, by making themselves more visible (and not only their subordinates), and to present authority at a distance, through control, which they conceive of as a means of emphasizing their identities as managers. These observations, which have been scarcely studied so far, suggest the need for a deeper investigation of the politics of the construction of managerial identity and authority in NWW, by analysing the visibilizing process of the manager. To that end, we develop a Foucauldian framework on power and visibility, which helps us emphasize power dynamics embedded in a political economy of visibility.

\section{A Foucauldian framework}

The philosophy developed by Michel Foucault presents a powerful heuristic slant in the field of management and organization research (Burrell, 1998), in particular to explore questions of authority and identity. Foucault indeed analyses ways to govern people, through his archeogenealogical approach of discipline, and manifests a strong interest for issues of power and visibility. 


\subsection{Foucault's archeo-genealogical approach of discipline}

In his early writings, called the "archaeological period", Foucault (1970) first examined the symbolic, social, and disciplinary effects produced by discourses, which create, legitimate, and control the objects they claim to know. This view emphasizes the power of discourses, which convey specific representations, and render visible, knowable, and governable the objects to which they apply (Barker, 1993; Sewell \& Wilkinson, 1992; Townley, 1993). Foucault thus recommends deconstructing the discourses that control the objects they claim to know. Later, in his "genealogical period", Foucault (1977) extended this view by focusing on modern ways and dispositives to govern, shape, guide, and influence people. Discipline, as a way to direct the conduct of others, constitutes the individual as a "disciplined subject". This approach highlights the hidden logics of influence, control, and power issues in the planned configuration of organizations, in which discipline relies on the instrumental uses of space and the materialization of power and hierarchies (Taylor \& Spicer, 2007).

In particular, Foucault (1977) is well-known for his conceptualization of power relations and their materialization (Taylor \& Spicer, 2007) through the notion of the "disciplinary gaze" described in the famous "panopticon" metaphor. The panopticon (which etymologically comes from the ancient Greek words opticon for "observe" and pan for "all") designates a prison design originally developed in the $18^{\text {th }}$ century by Jeremy Bentham, in which the observer (the guard) can watch all prisoners without prisoners being aware of this surveillance. The panopticon is a spatial arrangement in which the observer is at the centre and the observed are always visible and never know whether or not they are being actively watched. The architecture of the Panopticon conveys the sentiment of invisible omniscience and encourages selfdiscipline (Foucault, 1977). The aim of the "panoptical" mechanism of "watching and being watched" is to undertake potential constant surveillance that induces self-monitoring of those observed, by making them visible and observable, even when no one is watching them. Through his archeo-genealogical approach, Foucault thus draws the contours of a disciplinary society, in which discipline relies on discursive practices that create, legitimate, and control the objects they claim to know and physical dispositives (e.g., instrumental uses of space, "art of distribution", i.e., the distribution of individuals in space) materializing power relations (Taylor \& Spicer, 2007).

This view has largely inspired management and organization research to understand the material, spatial, and architectural aspects of control in modern organizations, especially in critical management studies (Jermier, 1998), as organizational spaces materialize spatial control 
and temporal discipline (Dale, 2005; Dale \& Burrell, 2008). The panopticon even appears as the "archetype" of control in organizations and has become increasingly popular in settings in which work is mostly performed using IT, which materializes power relations and supports the potential for continuous surveillance, even at a distance (Burrell, 1998; Zuboff, 1988). It has also been used as a metaphor to grasp more immaterial and symbolic forms of control, as well as a virtual aspect of discipline developed through technology and discursive practices. In the end, this approach emphasizes how the subjects of observation are rendered visible, knowable, and governable (Barker, 1993; Sewell \& Wilkinson, 1992; Townley, 1993) and thus constituted as objects of discipline and the exercise of power.

\subsection{An original view of power embedded in a political economy of visibility}

Beyond this well-known panopticon metaphor, a major contribution of the Foucauldian perspective lies in its original view of power at the heart of this archeo-genealogical approach, which seems particularly insightful to make sense of our research question. Rather than focusing on people's sources of authority, Foucault considers the practices, technologies, and apparatuses that support the exercise of power, which allows him to analyse the complex situations in which power is exercised and where subjects are constituted as visible and governable objects of knowledge and power. Power is not an attribute or a commodity that some people "have" or "get"; for Foucault, power is dynamic and permeates the social body, so it "must be analyzed as something that circulates ... that functions only when it is part of a chain" (Foucault, 1980, p.98). Because of this relational aspect, power is not associated with a particular institution but with "practices" (Townley, 1993, p. 520) that create and cause the emergence of new objects of knowledge that are rendered visible, knowable, and, thus, governable. Rather than determining "who has power" or "where power resides", Foucault invites the study of the "how" of power (its exercise) through an analysis of the "practices that give it effect" (Townley, 1993, p. 520).

This original vision of power is at the heart of a political economy of visibility within which subjects (the observer and the observed) are embedded. Foucault's view of power dynamics reveals that power relations are not merely negative but productive and creative as well, in that "power creates objects" of knowledge and power (Townley, 1993, p. 521). Power is productive in that it creates objects of knowledge that are rendered knowable, visible, and "governable" (i.e., the observed). As such, these objects of power provide a basis of action and intervention and, thus, of the exercise of power by the observer. The rationality behind this idea is that before someone or something can be governed or managed, it must first be known and, thus, visible. 
This original view of power is indeed framed in a political economy of visibility (i.e., "rendering something or someone visible", Townley, 1993, p. 520), according to which "power is exercised by virtue of things being known and people being seen" (Foucault, 1980, p. 154). This Foucauldian relational view of power thus implies that "power becomes apparent when it is exercised" (Townley, 1993, p. 520). This implies that power needs to be exercised, manifested, and perceived by subjects and that this exercise needs to be known, apparent, and visible (even if often unverifiable; Foucault, 1977) for power and authority to exist as such. This Foucauldian framework thus suggests a more comprehensive view of the principle of visibility, by showing that it is not only "the governed" (the observed) who are rendered visible as an object of discipline but also the "the governor" (the observer) who needs to be known and visible to exist as such.

Foucault's "political economy of visibility" is thus particularly helpful for understanding the power dynamics observed in NWW (as a disciplinary apparatus of power that materializes intentional ways of making visible and knowable the conduct of subjects and seeks to create specific modes of being). It also helps us make sense of the underlying construction of managerial authority, by shedding light on the political economy of visibility of the manager, who engages in different work practices with the goal of enhancing not only his or her visibility over remote employees but also his or her own visibility, thus translating his or her managerial capacity to govern and constitute the process of him- or herself. Thus, we empirically explore, by means of this conceptual framework, the manager's political economy of visibility in the context of NWW through an illustrative, ethnographic qualitative case study.

\section{Research methods}

\subsection{Research design and context}

We use a case study as part of a larger research project on NWW initiated in 2015, following a qualitative research method (Miles \& Huberman, 1994). The case study technique offers a research strategy that aids understanding of the underlying dynamics of certain phenomena. The case we studied is a real, medium-sized Belgian knowledge-based company specializing in digital transformation (approximately 110 employees) that we refer to as "the Company" (for anonymity reasons). It was founded in the 1990s and specializes in consulting and the selling of commercial knowledge-based solutions. We focused on new work practices in one of its divisions devoted to the digital transformation of organizations and the acceleration of digital 
businesses. In particular, we considered a team of 15 remote knowledge workers (junior and senior) led by a manager (a 42-year-old man, hereafter called "the Manager"). The remote employees have both a commercial and consulting mission and work on several projects at the same time, which requires strong reactivity and time optimization because clients are charged according to a fixed bid on a project-by-project basis. This case had several important qualities that sparked our interest.

This division was characterized by a context of restructuration, reduction of middlemanagement layers, managerial perceptions of job uncertainty, and high employee turnover, in line with the broader digital transformation of the group. In this context, it had recently developed NWW, by encouraging remote working in coworking spaces (CS) located around Belgium for remote employees. Remote working was thus re-spatialized (Halford, 2005) in eight CS that the Company had previously identified, in a context in which working from home was not officially permitted.

Also labelled the "unoffice" (Spinuzzi, 2012, p. 412) and often regarded as the new model of work (Gandini, 2015), coworking serves as part of a larger movement towards distributed work (Spinuzzi, 2012), in which mobile workers are reported to enjoy a self-directed, flexible working style (Gandini, 2015). Defined as a "philosophy", these innovative and alternative spaces with their coworking values are purported to be at odds with traditional corporate values and traditional managerial and corporate norms (e.g., Spinuzzi, 2012). However, recently, scholars have begun to address the tensions of practices developed in those spaces, in particular between the pretended "coworking's counter-corporate identity" and "recapitulation of neoliberal norms" (De Peuter et al., 2017, p. 689; see also Gandini, 2015).

The CS we studied were developed starting in January 2014 on the initiative of local Belgium authorities. Unlike shared CS founded through the individual initiative of freelancers or startups, these CS are funded by public authorities and companies through public-private partnerships. They are located in large cities and are part of a network of small to medium-sized CS that function similarly (i.e., in terms of their business model, objectives, pricing scale, and population organization). Each space is managed by a person, the coworking space operator (CSO), who is in charge of creating and animating the larger community of coworkers for collaboration, networking, and support, as well as ensuring the profitability of the space by completing rental contracts. These CSOs also must staff the front desk and maintain the daily operations of the space and coworkers; they serve as human links among coworkers or between salaried coworkers and their own company. 


\subsection{Data collection}

To explore the evolution of managers' roles and identities and the visibilizing process of the manager, it was essential to investigate the relationships among remote professionals, their manager, and the CSO as well as the evolution of practices and how remote employees perceived their manager's role and identities through this re-spatialization of their work.

Empirical material (which was collected from March 2016 to May 2017 and involved ethnographic fieldwork conducted by the author and a master's student) included guided tours of three of the CS, non-participant observations, research diary entries, semi-directive interviews, and informal discussions with various respondents, along with reviews of the literature on managers' identity and control missions and NWW. For our direct field observations, we followed a team of remote knowledge workers in the three CS. We spent a combined 20 days working in the CS to become immersed in the collective atmosphere. Our primary data also include 20 semi-directive interviews, each of which lasted 35 min-2 hours, conducted with the Manager, the remote employees, the human resource (HR) manager, the CSO of each space, and the coordinator of the Belgian network of CS. The interviews were conducted either in the CS or in the office's headquarters. Informal discussions were also held with other managers at the Company and with coworkers inhabiting the same CS. We prepared interview guides in advance, in accordance with the prior literature, and adapted the guides to each type of respondent.

We aimed to explore both how the Manager conceived of his role and identity in the context of this re-spatialization of the activity of employees in CS and how the employees perceived the role (and possible evolution) of the Manager and their relationship with him through this NWW. The main themes of the interviews thus pertained to the relationships between the Manager and his subordinates, evolutions of this relationship implied by the re-spatialization of work, experience of a typical workday, power issues, the benefits and negative aspects of managing and being managed in such situations, the achievement of managerial authority at a distance, and the role of space and material artefacts in managerial relations and control processes. The interview guide remained flexible enough to allow other themes to emerge (e.g., the Manager's staging of his visibility, legitimacy issues, questions of meanings, spatial and material dimensions). Secondary data included internal documentation, pictures, and press reviews of the CS. 


\subsection{Data analysis}

We used an iterative and abductive approach to develop a conceptual understanding of the empirical tensions we observed in recent research and in our data about changes in the Manager's role and identity in NWW. Beginning from the observation that the Manager's role and identity generally oscillate between an allegedly eroded managerial authority and the recapitulation of traditional modes of management in the context of post-bureaucratic NWW, we aimed to highlight, through our Foucauldian framework, how the Manager's identity and authority were constituted and evolved through the re-spatialization of the work of remote employees.

To that end, as advocated by Foucault, we aimed to deconstruct official narratives and discourses to understand the underlying power relationships behind the adoption of NWW. Foucault's approach is indeed embedded in a dialogical perspective that reclaims the political as an intrinsic part of organizational experience and practices (Deetz, 1996). Dialogical studies focus on the constructed nature of people and reality and emphasize the potential disunity of any discourse (Deetz, 1996). Thus, we subjected our material to a "deconstructive analysis" with the aim to identify underlying forces and effects of organizational discourse on NWW. Specifically, we wanted to understand the latent reasons behind the re-spatialization of remote work in CS and its relationship to the identity construction and visibilizing process of the manager. To structure our analysis, we also subjected our field notes to a content analysis using an iterative process of thematic coding, in accordance with established qualitative research practice (Richards, 2005). In this iterative approach, we went back and forth across the different data sources (e.g., fieldnotes from observation, interviews, and notes from informal discussions), emerging themes, and extant literature on the role and identity of the manager, especially in the context of NWW, through three steps (Richards, 2005) (Table 1).

\begin{tabular}{|l|l|}
\hline Step & Application to our data \\
\hline $\begin{array}{l}\text { Descriptive coding } \\
\begin{array}{l}\text { Storing information } \\
\text { that describes the case }\end{array}\end{array}$ & $\begin{array}{l}\text { We described the roles of people and activities they perform, contextual } \\
\text { elements about the restructuration of the division and the re-spatialization } \\
\text { of work, and ideas developed by people to describe their practices and } \\
\text { relationships. }\end{array}$ \\
\hline $\begin{array}{l}\text { Topic coding } \\
\begin{array}{l}\text { Allocating passages to } \\
\text { topics that correspond } \\
\text { to conceptual entities }\end{array}\end{array}$ & $\begin{array}{l}\text { The main constructs related to evolutions in the role and identity of the } \\
\text { Manager and in the relationships among organizational actors (in particular, } \\
\text { the Manager, remote employees, and CSOs) and the nature and evolutions } \\
\text { of control systems, for example, through the identification of logics of } \\
\text { empowerment and logics of disciplinary control that emerged from the } \\
\text { practice of re-spatializing the activity of these professionals in CS. We also } \\
\text { noted references to notions of visibility and invisibility, presence and } \\
\text { absence. }\end{array}$ \\
\hline
\end{tabular}




\begin{tabular}{|l|l|}
\hline & $\begin{array}{l}\text { We also coded the material, physical configuration of the CS, deliberately } \\
\text { planned elements of the NWW, and discipline logics favouring visibility } \\
\text { and highlighted the intentions of various stakeholders. }\end{array}$ \\
\hline $\begin{array}{l}\text { Analytical coding } \\
\text { Defining } \\
\text { interpreting and } \\
\text { meaning of extracts in } \\
\text { their context }\end{array}$ & $\begin{array}{l}\text { Exploration of the discursive (Allard-Poesi \& Laroche, 2018) and symbolic } \\
\text { aspects related to the re-spatialization of remote work to understand the } \\
\text { justifications and representations of the Manager's role attached to this } \\
\text { NWW and the underlying goals pursued with the re-spatialization of remote } \\
\text { work. We analysed more precisely how the Manager talked about his roles } \\
\text { and identities, in this new environment; we also specified how the } \\
\text { employees and CSOs talked about him and his (multiple) identities and } \\
\text { practices (during official interviews and unofficial discussions). Finally, we } \\
\text { analysed how remote employees experienced the re-spatialization of } \\
\text { working in CS and what this implied for the representation and construction } \\
\text { of the Manager's authority, role, and identity. We highlighted some } \\
\text { tensions and paradoxes in the Manager's intertwined roles and identities } \\
\text { and tied these tensions to his political economy of visibility, showing how } \\
\text { he staged his own visibility to manage his invisibility. }\end{array}$ \\
\hline
\end{tabular}

Table 1: Three steps of thematic coding

The adoption of a Foucauldian framework helped us distinguish between the official rationale for NWW and the latent motives below the surface (i.e., unstated reasons for the respatialization in a CS and underlying managerial goals pursued in this reconfiguration of remote work). Our case particularly highlights how NWW (based on the notions of empowerment, autonomy, collaboration, and openness) can be underpinned, paradoxically, by a desire for more worker control—not for a control purpose per se, but for other underlying reasons related to questions of legitimacy and identity (Väland \& Georg, 2018), as shown by the Manager's willingness to erect new symbolic analytical spaces and physical boundaries (in the CS) that facilitate his visibility, identification, and constituting process.

In this regard, our analysis unpacked the roles and identity of the Manager, which appeared as “controversial objects" (Callon, Lascoumes, \& Barthe, 2009). This notion seemed particularly promising to grasp the tensions we observed in the field about the Manager's experienced and perceived role and identities. Mobilizing this notion as a "sensitizing" concept, we thus made sense of the multiple identities of the Manager as a controversial object, comprising mixed and intertwined roles. In particular, our deconstructive analysis revealed how the Manager built a discourse on NWW to present himself as an enabler (see section 5.1). At the same time, he materialized his function through the construction of an apparatus of surveillance that helped him rebuild the principles of managerial visibility over his remote employees (see section 5.2). In doing so, the Manager's potential for action became itself more apparent and visible, even if its effective activation remained unverifiable (Foucault, 1977), thus restoring his authority (see section 5.3). The interpretation of our empirical analysis thus helped us understand the 
constituting process of the Manager as a visibilizing process, through which he legitimated his role, materialized his function, and restored his authority.

\section{Findings: Constituting the Manager as a visibilizing process}

Analysed through the lens of the Foucauldian "political economy of visibility", our findings highlight a process through which the Manager's intertwined roles and identities appear as a controversial object, evolving through spatially organized power dynamics (e.g., in the CS). This process suggests that the Manager staged his own visibility, in a context of delayering and work distantiation that tended to make him rather invisible. Through this process, he engaged in different practices with the goal of strengthening his control, restoring his authority, and shaping his managerial identity. This process gave meaning to the Manager's sense of self and granted visibility to his potential for action. Hereafter, we describe this becoming process of the manager as a visibilizing process, through which he legitimated his role (as an enabler), materialized his function (as a controller), and restored his authority (as a chief).

\subsection{Legitimating his role: The Manager as an "enabler"}

Our findings reveal how the Manager built a discourse on the re-spatialization of his remote subordinates, to justify this practice and legitimate his role, while sweetening the pill of this new (potentially constraining) practice for workers. Our deconstructive analysis shows how, through this NWW, the Manager gave legitimacy to his role by presenting himself as an "enabler" who listens to the needs of his subordinates and supports their work. By describing the CS as a "space of aspiration", the re-spatialization of the activity of the remote employees in CS was discursively constructed as a way initiated and developed by the Manager to address their needs, as both a result and symbol of his supporting and enabling role in the company. While the re-spatialization of the professionals' work in CS could have initially been perceived negatively as a constraint (i.e., a managerial attempt to control them), our deconstructing analysis shows how the Manager tried to influence the actions and perceptions of his remote subordinates through symbolic and discursive practices that attributed meaning to and justifications for his role and attributed imaginary aspects and significance to the NWW. The recourse to CS was officially legitimated and discursively constructed through specific managerial discourses that put emphasis on the Manager's recognition of the need for more employee well-being, autonomy, flexibility, and empowerment. The CS were indeed described by the Manager in official presentations as "a new generation of workspace, apart from the 
home or office", which would "enhance employees' well-being". This NWW was thus discursively constructed officially as practices of freedom, well-being, and self-development and presented to employees in a positive manner, as a way conceived of by management to help them "avoid isolation" and "gain autonomy and empowerment". The Manager stressed that his employees would be able to better decide how to organize their activity on a daily basis: "[you] don't have to go back to the headquarters or to the physical offices of clients as often as before". The HR manager similarly insisted on "the need to develop such solutions, in a context of increased commuting distances.... Thanks to the development of enabling IT, we can now take into account the preferences of a new generation of employees". The managerial discourses were thus virtually unanimous when it came to presenting the CS as imaginary spaces of aspiration, translating the Manager's (purported) empathy and understanding of employees' inner needs and expectations.

By doing so, the Manager not only attempted to satisfy his employees but also gave meaning to his role as an "enabler". Our analysis reveals how he stressed, in formal and informal discussions with his employees, his willingness to listen to their needs and his constant availability for them. For example, he noted: "It's important to show them that I am there. I'm always there to help them. If they have any problem they know they can count on me". $\mathrm{He}$ further added: "I had realized it was sometimes difficult for them to commute on long distances. This solution has been put in place to help them". By developing this NWW, he progressively built the new organizational arrangement as a space of aspiration and thus constituted his employees as (knowable and visible) objects of interest and attention. Simultaneously, he presented himself, through discursive practices that constituted remote workers as objects of attention and of interest, as an enabler, a "facilitator", a "supporter" (as mentioned by some employees), and a legitimate listener of their needs.

Such support also entailed supporting employees' work and performance and ensuring that they could fully contribute. It meant, in the Manager's discourse, providing his employees with a more flexible, productive, and adapted work environment than a home or other alternative (e.g., cafés). CS were presented by management as alternatives to the home office, offering a more professional atmosphere that allows professionals to avoid distractions and be more efficient and productive. The CSOs insisted on providing such an atmosphere in the CS, often associated with an open culture, a narrative of freedom and participation, and coolness, which contrasts with traditional workplaces. These benefits of CS were conveyed by the Manager, who emphasized the "unexpected benefits of working in these spaces that offer ways to innovate 
through unexpected serendipitous occasions, by enabling employees to meet people from other companies". The Manager explained how working in such spaces was an opportunity for employees to develop their business and increase their performance, thus presenting him, again, as an enabler, a coach, and "career adviser" (in the words of some employees) helping them increase their performance.

This discursively constructed legitimation process of the NWW obviously covered other underlying intentions and goals for management (e.g., the NWW were a means to minimize real estate costs, to give the image of a socially responsible corporation, or to signal modernity and attract a young, promising workforce). The Manager used the metaphor of a "safety valve", noting that "for us, these spaces are like a safety valve.... We needed to change our work environment, to be more agile and look more modern, to give the image of an innovative company in the way we work". The coordinator of the three CS also explained that these practices were part of broader corporate strategies that aimed to show employees that they were given the choice to work where they want and how they want, though, paradoxically, they were not allowed to telework at home. As the Manager notably summarized,

The workspace is a lever of performance, a real tool of management, which, when carefully thought, can result in more efficacy. We need to rethink the office. People want more flexibility, more mobility; they want a friendly atmosphere. They don't want the space to dictate their functions or hierarchical grade.... Let's give them what they want, or let's show them and give them the conviction that we give them what they want....

Management thus had clear underlying business-driven motives for introducing this NWW, which constituted remote employees as objects of interest and attention and shaped the Manager's role, by enabling him to appear to his subordinates as a facilitator and a coach, seemingly enabling telework, while introducing more control over them. Thus, in the end, in a context that had made the Manager almost invisible and his authority less palpable, he built, through this NWW, his image as an enabler, a coach, a supporter, and "almost a friend" (as mentioned by an employee), emphasizing the need to develop nice and warm relationships, as he explained. Through this re-spatialization of remote working, the Manager initiated a legitimizing process of his role, characterized by empathy and listening and understanding abilities of his employees' needs. "They are far ... from me, and from their colleagues. We need to be closer in our relation", he explained. Doing so, he also progressively introduced the idea that the recognition of their performance required a closer relationship, implying a better knowledge and awareness of their involvement and visibility over their actions. 


\subsection{Materializing his function: the Manager as a "controller"}

Beyond the official rationale, our deconstructing analysis helps understand how the Manager attempts to re-materialize himself as a manager in the organization (at a distance) through the development of an apparatus of surveillance underlying the re-spatialization of work in CS. Beyond managerial discourses about the ideal and imaginary dimension of CS involving autonomy, flexibility, and self-control, this NWW was actually a materialized alternative to working from home; it gave the Manager more visibility over the employees by reproducing a real office environment that encouraged productivity, responsiveness, efficiency, and control, even if outside the traditional physical boundaries of the company and direct managerial supervision. The re-spatialization of the activity of remote professionals had been developed in a context in which working from home was not officially permitted, as it generated all sorts of fears for management. As a CSO explained:

These spaces were initially thought up for freelancers, but CS now seduce more and more companies who see in such spaces an alternative to the routine of the classic workspace, the office - all the more that telework is not really taking off in this country, from both employers and employees, because there is still suspicion about the productivity of homeworkers.

During an interview, the Manager recognized (if not officially) the risk of loosening his authority at a distance with the generalization of working from home, explaining "the fact that client companies and [I] were not in favour of homeworking", given the "enduring demands to be able to see" and "supervise work". According to a CSO, "when people work at home, their company or clients can never be $100 \%$ sure that they are really working on what they are expected to". Thus, despite strong management through objectives, self-discipline, commitment from these professionals, and socio-ideological control (due to the collectively shared values and principles of the profession), the Manager surprisingly expressed the need to rely on more direct means of control (e.g., direct feedback from clients, more visibility over employees). This NWW, for management, offered such means. The HR manager noted,

Our managers usually put a brake on the development of telework as they want to preserve the team spirit and are reluctant to give up their mode of organization and their control.... Coworking is for us an excellent opportunity to solve these issues and accelerate the development of work practices outside the company's walls.

Our content analysis revealed that the NWW actually offered the Manager a way to rematerialize his traditional function, as if being an "enabler" was not sufficient to be perceived, in his view, as a manager vested with formal authority. The re-spatialization of remote work in CS replicated the Manager's traditional role at a distance, reproducing the actual working 
conditions and exerting novel forms of control in unexpected directions, given the nature of the remote employees' job (and despite their supposed operational autonomy). The Company had already received - and refused — requests from employees to work at home; it decided instead to encourage telework in CS that it had previously identified, which avoided some of the drawbacks of working from home and provided a way to reassure management and clients about the actual activity of the professionals.

Thus, far from discourses empowering employees, re-spatializing the activity of remote workers in such spaces was actually far more disciplining and constraining for them than before (forcing them to be more transparent in the way they organized and reported their daily activities). Our findings highlight underlying political issues through influential processes of configuring those practices. We uncovered paradoxical tensions between the official discourses conveyed by management to justify the re-spatialization of remote work in CS and the underlying disciplinary logics found in this NWW, especially in the form of physical artefacts that were at odds with the official discourse of self-development. For example, the CSOs worked closely with the managers of the companies that used these spaces to help them develop novel dispositifs of management and control (e.g., "visiting figures", "levels of attendance" detailing the attendance of employees in the spaces). A CSO explained that an important underlying goal of these practices is "to reassure managers and HR directors, who often look unfavourably on homework or remote work". He added that the practice of working in CS has a control function from which the company clearly benefits, explaining:

The company grants employees the working conditions they ask for. They grant them with a "pseudo-freedom", while attributing membership cards to them, which enable management, potentially, to trace their route.... The goal is to put a toolbox at the disposal of managers to help them really manage their team at a distance.

The use of attendance sheets, memberships, and swipe cards to record who is present (or not) conflicts with the official discourse of self-reflexivity and self-control. The Manager justified it as a legitimate procedure, given the Company's financial investment in the workspaces. Specifically, "it is normal to use these workspaces at their full capacity. We have now the means to introduce a bit more control over the activity of our employees in order to satisfy our clients, or at least give them a precise justification of our prices, so why should we do without it"? He also admitted that the deployment of professionals in CS enabled him, in the end, to gain more "precise visibility" at a distance over their behaviour and activity (i.e., technocratic and behavioural control; Alvesson \& Karreman, 2004). 
Our observations thus revealed how this NWW was conceived of as a panoptic "apparatus of government" and a way to control employees' conduct, thus revealing how power became embedded in the materiality of the CS and in the relationship between the Manager and his subordinates, such that expected and desirable behaviours were inscribed in the facilities, the constraints on the use of these spaces, and the spatial arrangements (Foucault, 1977). CS were actually conceived of by management as a tool to restore visibility over remote employees at a distance that served conflicting purposes: giving employees the impression (or illusion) that the NWW would serve their interests and provide them with more autonomy and well-being, while materializing the Manager's function and ensuring his control over his subordinates at a distance. The NWW were thus a suitable means for the company to regain some visibility over remote employees' activity, while seemingly addressing their increasing demands for telework and more flexible ways of working (and simultaneously avoiding the practice of working from home viewed by management as too risky because it could erode the perceived authority). The Manager used the CS as an apparatus to rebuild the principles of managerial visibility and rematerialize their presence, thus supporting the exercise of power. He reintroduced a material presence (at a distance) with the support of the CSOs through this new potential of control. In doing so, he created a new form of governmentality at a distance supported by his discourse, replicating the traditional constitutive role of the manager, as if control was a prerequisite to be perceived as a manager. The CS offered a new analytical space that rendered visible and governable the activity of these remote professionals.

\subsection{Restoring his authority: the Manager as "chief"}

The re-spatialization in CS constituted a new arena of knowledge that gave the Manager a basis for action and intervention and, thus, the exercise of power. In the end, not only did the activity of remote workers become more visible, but so, too, did the Manager's presence at a distance. The Manager rendered his authority more apparent, visible, and perceptible and translated his supposed potential for observation and control in the eyes of his subordinates. In doing so, the manager appeared as "the chief", vested with a certain authority and power to judge his subordinates' work.

Beyond this potential for control and supervision, however, the Manager, in informal discussions, acknowledged that he did not effectively use his potential for control, but simply tried to "make more transparent" and thus visible such a "possibility for more control" (i.e., making the exercise of power know and visible, even if unverifiable; Foucault, 1977). The Manager's regained potential for control enabled by the NWW mostly helped him solidify his 
legitimacy as a manager (as the chief of his team) and restored perceptions, both among his subordinates and internally (in his own hierarchy), of his managerial authority. In a complex context marked by a recent reorganization, modification of the perimeter of action of directors, and suppression of some middle-management positions, we observed that the Manager himself identified his role as having to show in a clear, visible, and knowable manner his performance towards his own manager and the executive committee, for example, by "providing more visibility on the attainment and progression of his objectives", as he explained (e.g., the number of new businesses obtained through collaborations developed in the CS, demonstrations of how he managed his team and achieved the creation of healthy emulations among his subordinates). The re-spatialization of the work of his remote subordinates also enabled him to justify his role among his employees and identify himself within this role. For example, he explained the importance of showing "who is the chief in distant situations that are sometimes complex to manage". He added, paradoxically, that "control and supervision are still part of [my] role ... even if I don't effectively always supervise them [subordinates], it's good for some of them to know that I do so or that I can do so". The CSOs confirmed that enabling remote work in CS is particularly useful for managers to reassert their authority, as they seldom see team members face-to-face and communicate mostly by digital means. The Manager sought to demonstrate his added value to his subordinates through the use of tactics (e.g., IT uses such as instant messaging, calls, videoconferences) or at least through his potential for supervision embedded in this physical, material, and spatial arrangement of the space to make them behave and embrace specific values and performance norms (Dale, 2005; Halford, 2005). Thus, the CS, as laid-out, well-organized "new agora" (in one CSO's words), "give managers new possibilities of action, reassure them, and confirm them in their role and identity as managers ... a fortiori when nomadism used to become widespread on Fridays"!

Most employees experienced these CS as spaces of flexibility, which enabled continuity in their activities across various workspaces, gave more structure and visibility to their work, and signalled their engagement to their manager.

Furthermore, these professionals embraced the re-spatialization of their work as a way to ensure that their activity was more visible and recognized by their manager. For example, although they could work anywhere in the area, people appropriated the CS by creating their own "individual workspace", tacitly using the same desk or chair in the same area to establish a "comfort zone" (as in the Foucauldian art of distribution). By following some behavioural rules that were implicitly co-constituted, they provided better visibility of their own individual 
presence or absence in the spaces to their peers and the CSO and, thus, indirectly to their manager who had the possibility (even if not always activated) to know where they were and how they worked. Their embodied experience extended the principles of enclosure and distribution in the panopticon (Foucault, 1977) through the deliberate creation of informal spatial structures that made them more visible to management.

In doing so, they legitimated the role of their Manager, whom they viewed as "a chief", an "evaluator of their performance" at a distance, a "judge" of their engagement, and a "guarantor of their progression". Through their experiences and reactions, the employees ended up restoring the Manager's authority. The NWW thus served as a means that provided visibility not only of the employees' activity, making them more knowable and governable, but also of the Manager, whose potential for action and intervention itself became more apparent, even if its effective activation remained unverifiable (Foucault, 1977). This practice rendered the Manager's potential of control more visible and perceptible and, at the same time, provided meaning to his actions. The Manager ended up being constituted in such power dynamics as a "manager" and identified himself as a manager, endowed with traditional forms of authority, as an integral part of his identity. His visibility as a manager by employees was thus essential to reaffirm his authority.

\section{Discussion}

In a context in which distantiation (Sewell \& Taskin, 2015; Taskin, 2010) is becoming the new normal, and where the traditional figure of the manager is eroded, we examine how managers assert their authority by staging their own visibility. We highlight a political economy of visibility that applied not only to the subordinates, rendered visible, knowable, and governable (as objects of knowledge, discourse, and attention), as indicated in management research (Dambrin, 2004; Sewell \& Taskin, 2015; Valsecchi, 2006), but also to the Manager himself, whose space of action and raison-d'être were constituted in such power dynamics and the subtle interplay of visibility and invisibility. In particular, we show how the constituting process of the Manager relies on a visibilizing process, which entails legitimating his role, materializing his function, and restoring his authority. We thus highlight a reversion of classic logics of visibility found in traditional management and organizational literature, in which visibility generally applies to the work of employees, who are made more visible, knowable, and governable at a distance. Our research reveals how this visibilizing process also applies to the 
manager, whose authority needs to be made apparent, manifest, and visible, such that power can be exercised and the manager, who sees to be seen, can exist as such. Thus, our contributions are twofold: first, this study informs research on the identity-building process of managers, by highlight a "political economy of visibility" that sheds light on classic contradictions observed in empirical studies on the manager's role; second, it contributes to the legitimating process of managers; by showing how they materialize their presence, the study emphasizes the spatio-material dimensions of the constitution process of the manager aiming to manage meanings and perceptions.

\section{1. "Seeing to be seen": the Foucauldian political economy of visibility applied to the manager}

Our Foucauldian frame helps conceptualize the constituting process of a manager and multiple identities as a "controversial object" (Callon et al., 2009). Surprisingly, NWW (i.e., the respatialization of work studied herein) based on the notions of empowerment, autonomy, collaboration, and openness, in which the manager appears as an enabler and a coach, are not deprived of conventional control exerted by a manager who functions as a potential supervisor and controller of performance.

By applying a political economy of visibility to managers, our study helps make sense of the tensions between managers' mixed roles and their intertwined identities traditionally found in management literature. The Foucauldian relational view of power suggests that "power becomes apparent when it is exercised" (Townley, 1993, p. 520). Foucault (1980) indeed emphasizes the political dimension of visibility through power. Applied to our case, this political economy of visibility demonstrates that the NWW introduces an analytical space in which the activity of remote employees is rendered knowable, visible, and governable. It is because remote employees can be known and seen that managers are made visible (physically or symbolically), are constituted as an observable reality, and appear as "managers", according to the perceptions of their subordinates, the hierarchical structure, and themselves. The new practice not only renders the subjects of power (i.e., the remote employees) knowable and visible but also renders the authority of the manager more apparent and visible, such that power can be exercised and the manager, who sees to be seen, exists as such.

According to prior research, "[c]orporations are bureaucracies and managers are bureaucrats. Their fundamental tendency is toward self-perpetuation. They are, almost by definition, resistant to change" (Murray, 2010, p. 84). Our study helps problematize such resistance by showing that being a manager, existing as a manager, and remaining as a manager ultimately 
require having people to manage and then being able to show and justify the managerial role by rendering such people visible, despite their physical dislocation. Grensing-Pophal (1999) reports an anecdote of a manager who recalls his boss coming out of his office, looking at the empty cubicles around him, and saying, "What do I need you for?" (Cascio, 2000). The question raised by managers in NWW such as remote work environments has long been "How can I manage people if I can't see them?" but another important question also exists for managers, despite the relative lack of attention to it: "How can I be a manager if I cannot show I have a team to manage?"

Managers legitimately may wonder if they will still be valued by their companies if they are managing employees who are not physically present (Cascio, 2000), especially in increasingly virtual and remote contexts marked by delayering and characterized by the rhetoric of selfmanagement, holacracy, employee empowerment, and global discourses about the uselessness, and even the end, of management (Hamel, 2011; Koch \& Godden, 1997; Leavitt, 2003) that is associated with managers' perceptions of increased job insecurity and career uncertainty (Foster et al., 2019). Managers are under increased pressure to justify their existence and value (Taracki, Heyden, Floyd, Raes, \& Rouleau, 2019). Our case study shows how, in a context of organizational restructuration that questions the legitimacy of middle management (Balogun \& Johnson, 2004), the Manager staged his own visibility to manage such invisibility and constituted his multiple identities in this process.

In doing so, our study calls for an extension of the famous Foucauldian "panopticon" metaphor to apply its logics to the "guard in the tower", the observer, and the manager. The panopticon is characterized by "invisible surveillance" and a depersonalization of power (Foucault, 1977) and mainly focuses on the subordinates - the subjects of control and objects of power-at the expense of those who control - the managers as guards. Our findings suggest that the latter are also enmeshed in a panoptic system, as shown by the Manager's need to report to his hierarchy and identify with his expected role, and a political economy of visibility such that they need to be seen to exist.

\subsection{The meaning of management: a spatio-material "management of meaning"}

By highlighting the interplay of invisibility and visibility in the construction of the manager's role, this study contributes to research on the managers' legitimating process and identification with their roles. The way managers build their identity and identify with their roles is an underresearched area of managerial work, in which more understanding is necessary beyond simple 
notions of commitment (Foster et al., 2019). Beyond its limitations (e.g., a single case study), our research contributes to this literature by highlighting how managers construct their identities (Foster et al., 2019) and influence perceptions of their roles, by reproducing management systems and practices that work to recapitulate traditional regimes of control. The novelty of this study is not to specify the resurgence of bureaucratic forms of control in NWW (Sewell \& Taskin, 2015) but rather to highlight the active meaning-making processes embedded in the legitimating process of the manager; the study anchors the roles and multiple identities of managers in the persistence of traditional regimes of control through an analysis of power dynamics and their embeddedness in a political economy of visibility.

In line with the recent spatial and material turn in organization studies, the findings emphasize the extent to which now, more than ever, the workplace contributes to the constitution of perceived identities and meanings and is involved in questions of legitimacy and organizational politics (Blakstad, 2015; de Vaujany \& Vaast, 2014; Väland \& Georg, 2018), which are crucial to the construction of the role and identity of managers. Although liquidity (Bauman, 2000), flexibility, and distantiation have ironically distracted researchers from the importance of spatial and material issues (Dale, 2005; Dale \& Burrell, 2008; Halford, 2005), they paradoxically have also increased the meaning of materiality (e.g., the physical place at work) in managerial relations (Blakstad, 2015) and identity construction processes.

Our study thus contributes to a recent trend in organization and management research that attempts to "rematerialize management" (Bass \& Steidlmeier, 1999; Hansen, Ropo, \& Sauer, 2007; Ford et al., 2017), in contrast with a dominant view that focuses on the disembodied traits and characteristics of managers. In a context that has tended to "dematerialize" management, to make it more invisible (both symbolically and physically), and to reduce managers to immaterial figures and abstract concepts, our research sheds light on the way managers materialize themselves (Ford et al., 2017) and constitute themselves as managers by staging their own visibility and giving legitimacy to their role.

The constitution of managers and employees has long been embedded in the manager's ability to locate employees spatially, in workplaces and beyond (Sewell \& Taskin, 2015; Taylor \& Spicer, 2007). Management has thus relied on the production of functional environments and buildings that enable surveillance and control, implying a disciplinary authority (Taylor \& Spicer, 2007). That is, the role of the manager has long been shaped and constructed by material workspace arrangements (Ropo et al., 2015), with workers and managers defined according to their close relationship and proximity in fixed workspaces. In this context, the CS we 
investigated re-introduced a distant but embodied and "analytical space" (Foucault, 1977) for managers to be materially present and to exist as managers (both for their distant team and internally for their superiors), so that they shaped the space (in its discursive formation and material configuration) and also were shaped by it (in their perceived role, identity, and constitution processes). These spaces contributed to an embodiment of the manager's work, power, authority, and legitimation processes, overcoming the spatial distance and dislocation of people (Halford, 2005).

Some organizational scholars have emphasized the materiality and spatiality of organizational legitimation processes. In this vein, this research emphasizes the spatial and material dimensions of the constitution process of the manager, who, paradoxically, in a context of work liquefaction, virtuality, and mobility, increasingly resorts to material places to reintroduce some control over remote employees and to influence the perceived representations of his or her mission. Thus, Gowler and Legge (1983) were right to define the meaning of management as the "management of meaning", which is now, more than ever, spatially and materially anchored. Managers largely draw on space and materiality as apparatuses of government (Foucault, 1977) to construct discourses and perceptions that manage the meaning of their role as managers. In line with current research on performativity in organizations, our research thus contributes to a relational consideration of authority and the revelation of its socio-material dimension (Bourgoin et al., 2019) as a social process and a co-constituted, continual accomplishment (Allard-Poesi \& Laroche, 2018; Taylor \& Van Every, 2014).

\section{References}

Allard-Poesi, F., \& Laroche, H. (2018). This is serious: Enacting authority during managerial conversations. Management, 21(1), 611-645.

Alvesson, M. (1995). The meaning and meaninglessness of postmodernism: Some ironic remarks. Organization Studies, 16(16), 1047-1075.

Alvesson, M., \& Karreman, D. (2004). Interfaces of control: Technocratic and socio ideological control in a global management consultancy firm. Accounting, Organizations and Society, 29(3/4), 423-444.

Aroles, J., Mitev, N., \& de Vaujany, F. X. (2019). Mapping themes in the study of new work practices. New Technology, Work and Employment, 34(3), 285-299.

Balogun, J., \& Johnson, G. (2004). Organizational restructuring and middle manager sensemaking. Academy of Management Journal, 47(4), 523-549.

Barker, J. (1993). Tightening the iron cage: Concertive control in self-managing teams. Administrative Science Quarterly, 38, 408-437.

Bass, B., \& Steidlmeier, P. (1999). Ethics, character, and authentic transformational leadership behavior. Leadership Quarterly, 10, 181-217. 
Bauman, Z. (2000). Liquid modernity. Cambridge: Polity.

Blakstad, S. H. (2015). Work isn't where it used to be. In A. Ropo, P. Salovaara, E. Sauer, \& D. De Paoli (Eds.), Leadership in spaces and places (pp. 49-68). Cheltenham: Edward Elgar.

Bourgoin, A., Bencherki, N., \& Faraj, S. (2019). "And who are you?" A performative perspective on authority in organizations. Academy of Management Journal. https://doi.org/10.5465/amj.2017.1335

Brocklehurst, M. (2001). Power identity and new technology homework: Implications for "new forms" of organizing. Organization Studies, 22, 445-466.

Burrell, G. (1998). Modernism, postmodernism and organizational analysis: The contribution of Michel Foucault. In A. McKinlay \& K. Starkey (Eds.), Foucault, management and organizational theory (pp. 14-28). London: Sage.

Callon, M., Lascoumes, P., \& Barthe, Y. (2009). Acting in an uncertain world: An essay on technical democracy. Cambridge, MA: MIT Press.

Carney, B. M., \& Getz, I. (2009). Freedom, Inc.: Free your employees and let them lead your business to higher productivity, profits, and growth. New York: Crown Business.

Cascio, W. (2000). Managing a virtual workplace. Academy of Management Executive, 14, 81-90.

Clegg S., Harris, H., \& Hopfl, H. (Eds.) (2011). Managing modernity: Beyond bureaucracy. Oxford: Oxford University Press.

Dale, K. (2005). Building a social materiality: Spatial and embodied politics in organizational control. Organization, 12, 649-678.

Dale, K., \& Burrell, G. (2008). The spaces of organisation and the organisation of space: Power, identity and materiality at work. London: Palgrave Macmillan.

Dambrin, C. (2004). How does telework influence the manager-employee relationship? International Journal of Human Resources Development and Management, 4, 358-374.

Dandeker, C. (1990). Surveillance, power and modernity: bureaucracy and discipline from 1700 to the present day. Cambridge: Polity.

De Peuter, G., Cohen, N. S., \& Saraco, F. (2017). The ambivalence of coworking: On the politics of an emerging work practice. European Journal of Cultural Studies, 20(6), 687-706.

de Vaujany, F. X., \& Vaast, E. (2014). If these walls could talk: The mutual construction of organizational space and legitimacy, Organization Science, 25(3), 713-731.

Deetz S. (1996). Describing differences in approaches to organization science: Rethinking Burrell and Morgan and their legacy. Organization Science, 7(2), 191-207.

Deffayet, S. (2002). Nouvelles technologies de l'information et de la communication et contrôle dans la relation managériale. Recherches Sociologiques, 1, 27-48.

Drucker, P. (1988). The coming of the new organization. Harvard Business Review, January-February, $45-53$.

Ezzamel, M., Lilley, S., \& Willmott, H. (1994). The "new organization" and the "new managerial work." European Management Journal, 12(4), 454-461.

Felstead, A., Jewson, N., \& Walters, S. (2003). Managerial control of employee working at home. British Journal of Industrial Relations, 41(2), 241-264.

Flamholtz, E. (1996). Effective organizational control. A framework, applications, and implications. European Management Journal, 14(6), 596-611.

Fleming, P. (2009). Authenticity and the cultural politics of work: New forms of informal control. Oxford: Oxford University Press. 
Ford, J., Harding, N. H., Gilmore, S., \& Richardson, S. (2017). Becoming the leader: Leadership as material presence. Organization Studies, 38(11), 1553-1571.

Foster, W., Hassard, J., Morris, J., \& Cox, J. (2019). The changing nature of managerial work: The effects of corporate restructuring on management jobs and careers. Human Relations, 72(3), 473-504.

Foucault, M. (1970). The order of things: An archaeology of the human sciences. London: Tavistock.

Foucault, M. (1977). Discipline and punish: The birth of the prison. New York: Random House.

Foucault, M. (1980). Power/knowledge. London: Harvester Wheatsheaf.

Gandini, A. (2015). The rise of CS: A literature review. Ephemera - Theory and Politics in Organization. 15(1), 193-205.

Gowler, D., \& Legge, K. (1983). The meaning of management and the management of meaning: A view from social anthropology. In M. J. Earl (Ed.), Perspectives on management (pp. 197-233). Oxford: Oxford University Press.

Grensing-Pophal, L. (1999). Training supervisors to manage teleworkers. HRMagazine, January, 67-72.

Hales, C. (2005), Rooted in supervision, branching into management: Continuity and change in the role of first-line manager. Journal of Management Studies, 42, 471-506.

Halford, S. (2005). Hybrid workspace: Re-spatialisations of work, organisa.tion and management. New Technology, Work and Employment, 20, 19-33.

Hamel, G. (2011). First, let's fire all the managers. Harvard Business Review, 89(12), 48-60.

Handy, C. (1995), Trust and the virtual organization. Harvard Business Review, May/June, 40-50.

Hansen, H., Ropo, A., \& Sauer, E. (2007). Aesthetic leadership. Leadership Quarterly, 18, 544-560.

Heckscher, C., \& Donnellon, A. (1994). The post bureaucratic organization: New perspectives on organizational change. Thousand Oaks, CA: Sage.

Hodgson, D. E. (2004). Project work: The legacy of bureaucratic control in the post-bureaucratic organization. Organization, 11, 81-100.

Jermier, J. (1998). Introduction: Critical perspectives on organizational control. Administrative Science Quarterly, 43(2), 235-256.

Johns, T., \& Gratton L. (2013). The third wave of virtual work. Harvard Business Review, JanuaryFebruary, 66-73.

Kallinikos, J. (2003). Work, human agency and organizational forms: An anatomy of fragmentation. Organization Studies, 24, 595-618.

Kanter, R. M. (1989). The new managerial work. Harvard Business Review, November-December, 8592.

Koch R., \& Godden, I. (1997). Managing without management: Post-management manifesto for business simplicity. London; Sonoma.

Kurland, N. B., \& Cooper, C. D. (2002). Manager control and employee isolation in telecommuting environments. Journal of High Technology Management Research, 13(1), 107-126.

Kurland, N. B., \& Egan, T. D. (1999). Telecommuting: Justice and control in the virtual organization. Organization Science, 10(4), 500-513.

Leavitt, H. J. (2003). Why hierarchies thrive. Harvard Business Review, 81(3), 96-102.

Lee, L., \& Edmondson, A.C. (2017). Self-managing organizations: Exploring the limits of less hierarchical organizing. Research in Organizational Behavior, 37, 35-58.

Miles, M., \& Huberman, M. (1994). Qualitative data analysis. Beverly Hills, CA: Sage.

Mintzberg, H. (1973). The nature of managerial work. New York: Harper \& Row. 
Mintzberg, H. (1983). Structure in fives: Designing effective organizations. Engelwood Cliffs, NJ: Prentice Hall.

Mintzberg, H. (1998). Covert leadership: Notes on managing professionals. Harvard Business Review, 76(5), 140-147.

Murray, A. (2010). The end of management. The Wall Street Journal, August 21, 84.

Ouchi, W. G. (1979). A conceptual framework for the design of organizational control mechanisms. Management Science, 25, 833-848.

Peters, T. (1992). Liberation management: Necessary disorganization for the nanosecond nineties. London: MacMillan.

Reed, M. (2005). Beyond the iron cage? Bureaucracy and democracy in the knowledge economy and society. In P. du Gay (Ed.), The values of bureaucracy (pp. 115-140). Oxford: Oxford University Press.

Richards, L. (2005). Handling qualitative data: A practical guide. London: Sage.

Robertson, B. (2015). Holacracy: The new management system for a rapidly changing world. New York: Henry Holt \& Company.

Ropo, A., Salovaara, P., Sauer, E., \& de Paoli, D. (2015). Leadership in spaces and places. Cheltenham: Edward Elgar.

Seibert, S., Silver, S., \& Randolph, W. (2004). Taking empowerment to the next level: A multiple-level model of empowerment, performance, and satisfaction. Academy of Management Journal, 47(3), 332349.

Sewell, G. (2012). Employees, organizations and surveillance. In K. Ball, K. D. Haggerty, \& D. Lyon (Eds.), The handbook of surveillance studies (pp. 303-312). London: Routledge.

Sewell, G., \& Taskin, L. (2015). Out of sight, out of mind in a new world of work? Autonomy, control, and spatiotemporal scaling in telework. Organization Studies, 36(11), 1507-1529.

Sewell, G., \& Wilkinson, B. (1992). Someone to watch over me: surveillance, discipline and the justin-time labour process. Sociology, 26(2), 271-289.

Spinuzzi C. (2012), Working alone together: Coworking as emergent collaborative activity. Journal of Business and Technical Communication, 26(4), 399-441.

Sveningsson, S., \& Alvesson, M. (2003). Managing managerial identities: Organizational fragmentation, discourse and identity struggle. Human Relations, 56, 1163-1193.

Swann Jr., W. B., \& Bosson, J. K. (2010). Self and identity. In D. T. Gilbert, S. T. Fiske, \& G. Lindzey (Eds.), Handbook of social psychology (5th ed., pp. 589-628). Hoboken, NJ: Wiley.

Taracki, M., Heyden, M., Floyd, S., Raes, A., \& Rouleau, L. (2019). Reconceptualizing middle's manager' roles in modern organizations. Call for Paper, Special Issue, Journal of Management Studies.

Taskin, L. (2010). La déspatialisation: Enjeu de gestion. Revue française de gestion, 202(3), 61-76.

Taylor, S., \& Spicer, A. (2007). Time for space: A narrative review of research on organizational spaces. International Journal of Management Reviews, 9, 325-346.

Townley, B. (1993). Foucault, power/knowledge and its relevance for human resource management. Academy of Management Review, 18, 518-545.

Väland, M., \& Georg, S. (2018). Spacing identity: Unfolding social and spatial-material entanglements of identity performance. Scandinavian Journal of Management, 34(2), 193-204.

Valsecchi, R. (2006). Visible moves and invisible bodies: The case of teleworking in an Italian call centre. New Technology, Work and Employment, 21, 123-138. 
Wiesenfeld, B. M., Ragurham, S., \& Garud, R. (1999). Managers in a virtual context: the experience of self-threat and its effects on virtual work organization. In C. L. Cooper \& D. M. Rousseau (Eds.), Trends in organizational behaviour (Vol. 6). Chichester: Wiley.

Zuboff, S. (1988). In the age of the smart machine: The future of work and power. New York: Basic Books. 